\title{
The examination of the personality traits and optimal performance mood of the university athletes
}

\author{
Ceviker A. ${ }^{\mathrm{ABCDE}}$, Ozlu K. ${ }^{1 \mathrm{ABCDE}}$, Deryahanoglu G. ${ }^{1 \mathrm{ABCDE}}$, Demirdoken C. ${ }^{1 \mathrm{ABCDE}}$, Turkay H. ${ }^{2 \mathrm{ABCDE}}$ \\ ${ }^{1}$ Faculty of Sport Sciences, Hitit University, Turkey \\ ${ }^{2}$ High School of Physical Education And Sports, Kafkas University, Turkey
}

Authors' Contribution: A - Study design; B - Data collection; C - Statistical analysis; D - Manuscript Preparation; E - Funds Collection.

\begin{abstract}
Purpose:

The aim of this study is to investigate the relationship between personality traits and optimal performance mood in response to gender, sports branch, weekly training hours of the athletes competing in the university league variables.

Material: $\quad$ A total of 250 volunteer athletes from 17 universities, 75 female and 175 male, participated in the study. 95 of the athletes are basketball and 155 are volleyball players. In addition to the personal information form which includes demographic information prepared by the researchers, "Optimal Performance Mood Scale" developed by Jackson and Eklund (2004) and adapted to Turkish by Aşçı et al. (2007) and "5-factor personality traits scale" developed by Benet-Martinez, John (1998) and adapted to Turkish by Schmitt, Allik, McCrae and Benet-Martinez (2007) were applied to the participants. Frequency analysis was applied in order to determine the participants' demographic information based on the statistical data analysis, and unpaired t-test was applied to determine the personal traits and optimal performance mood scores in response to gender, branch, weekly training sessions. Furthermore, in order to determine the relationship between that personal traits and optimal performance moods correlation test was applied. Statistical significance level was accepted as $p<0.05$.

Results: $\quad$ As a result of the analysis of the data obtained; while there was no significant difference between the athletes according to the gender variable, it was concluded that there was a significant difference between sports branch, weekly sport variables and personality traits and optimal performance moods. In addition, a positive correlation was found between the participants' personality traits and optimal performance moods as a result of the correlation test $(r=0,608)$.

Conclusions: $\quad$ This study has proved that personality traits and optimal performance moods effect one another positively and gender variable makes no significant difference. Yet, sport branches and weekly training hours makes meaningful differences between general and subscales scores.

Keywords: personality, optimal performance, volleyball, basketball.
\end{abstract}

\section{Introduction ${ }^{1}$}

Sports and performance are two complementary phenomena in contemporary sports. It is desired to have high-performance scores as a result of sportive activities. The importance of psychological factors has been revealed in scientific researches to improve the quality of performance. Therefore, it is important to examine the psychological structures associated with optimal performance in order to determine the psychological conditions that may contribute to performance [1].

Since it demonstrates the mental and psychological states resulting from the optimal performance experience during exercises; "Optimal performance mood/flow state" is an important phenomenon that needs further investigation [2].

The optimal performance mood concept was introduced into the literature as a result of the researches conducted by Csikszentmihalyi [3] in order to explain the reasons that lead individuals to free-time activities. It is defined as a state associated with self completion that means personality is integrated with thoughts,

\footnotetext{
(c) Ceviker A., Ozlu K., Deryahanoglu G., Demirdoken C., Turkay H., 2020

doi:10.15561/18189172.2020.0101
}

intentions, emotions and all these senses concentrate on the same goal. Optimal performance mood state tends to occur when a person encounters a clear set of objectives requiring appropriate responses. Unlike normal life, these "flow activities" allow a person to concentrate on clear and harmonious goals and provide immediate feedback. Flow also happens when a person's skills are fully involved in overcoming a challenge that is fully manageable. It, therefore, acts as a magnet to achieve new skills and to make things much more challenging. If the issues are less challenging, the person begins to resolve it by increasing them. If the issues are too much challenging it is possible to turn back to flow state after learning new skills [4]. Moneta [5] explains "flow" as the integration of the individuals' personal competences, purposes and their inner pleasure after a comleted activity. Asakawa [6], defines optimal performance mood as the optimal mental state which occurs when a person feels competent, highly motivated and takes pleasure during an activity.

Peak performance or optimal performance can be identified as an personal achievement in setting standards rather than specifying a psychological state. The optimal performance experience is closely related to the optimal 
performance mood and it is personal experience of a peak performance. The optimal performance experience does not always lead to the formation of an optimal performance mood [7,8]. This relationship occurs in skilled athletes with high performance and they achieve the optimal performance mood level when the task is difficult. Optimal performance mood can move the athlete to a higher leves of performance letting him have a state of consciousness that they have never thought before [7].

Considering it is as a part of life and struggle, the relationship between sports performance and athletes' personality traits should be examined carefully. Personality can be defined as distinctive and characteristic patterns of thoughts, emotions and behaviors which define the way an individual interacts with the physical and social environment [9]. It ncludes emotional, motivational and most importantly cognitive processes that influence how the individual behaves or feels in the performance experiences and that occur in their inner world. Pervin and John [10] define personality as qualities which cause individuals to differ in their performances due to their thinking and feeling ability and the resulting behaviour.

Personal traits are among the factors affecting optimal performance mood and take part in literature. Through several studies, it is concluded that while deppresive and anxious people have little opportunity to experience optimal performance mood; hardworking and neat ones are more likely to experience optimal performance mood [11].

In addition to the innate traits, the traits acquired as a result of the interaction with the environment are unique to person and differ from person to person. Therefore, different personality traits cause differences in optimal performance mood levels. To maintain a qualified and high performance the relationship between them should be taken into consideration.

Hypothesis:

H1: There is no relationship between personality traits of Unilig atlethes and their optimal performance moods.

H2: Gender variable causes no significant difference between personality traits of Unilig atlethes and their optimal performance moods.

H3: Branch variable causes no significant difference between personality traits of Unilig atlethes and their optimal performance moods.

H4: Weekly training duration causes no difference between personality traits of Unilig atlethes and their optimal performance moods.

\section{Purpose:}

In this context, the aim of this study to examine the affects of atlethes' personality traits to determine their optimal performance moods and analyse their personal traits in terms of gender, branch and weekly trainind durations variables. At the end of the study the researchers offer further suggestions to trainers and ones work at sports clubs so as to achieve a positive affection with atletes.

\section{Material and Method}

Participants.

In this study which examines the relationship between personality traits and optimal performance moods of athletes, relational screening model aimed to determine covariance and/or the degree between two or more variables from the general screening models was used [12]. The sample of the study consists of 250 athletes (75 female, 175 male) with 21.61 age average in 2 different branches (basketball and volleyball) from 17 different universities that participate in UNILIG competitions being held in Çorum province and present at 2017-2018 activity calender of Turkey University Sports Federation (TUSF).

\section{Research Design.}

In addition to the personal information form created by the researchers to determine the socio-demographic information of the participants within the scope of study, "Optimal performance mood scale" consisting of 9 subscales of 5 point Likert type (with 0.55 to 0.87 internal consistency coefficients) developed by Jackson and Eklund [13] and adapted to Turkish by Aşçı et al. [7] and "Five-factor personality traits scale" consisting of 5 subscales of 5-point Likert type developed by BenetMartinez and John [14] Schmitt and adapted to Turkish by Schmitt, Allik, McCrae and Benet-Martinze [15] were used.

\section{Statistical Analysis.}

Statistical analysis of the data was performed with the SPSS 22.0 package program and the normality of the data was tested with Kolmogorov-Smirnov. After determining the normal distribution of the data, unpaired t-test was used to determine the differences between the scores obtained from gender, sports branch, weekly sports hours, and personality and optimal performance mood scale and subscales. The relationship between the participants' personality scale scores and optimal performance mood scores was analyzed by correlation test. Statistical significance level was accepted as $\mathrm{p}<0.05$.

\section{Results}

Table 1. Demographic traits of unilig athletes

\begin{tabular}{lll}
\hline Gender & $\mathbf{f}$ & \% \\
\hline Female & 75 & 30.0 \\
Male & 175 & 70.0 \\
Branch & $\mathrm{f}$ & $\%$ \\
Basketball & 95 & 38.0 \\
Volleyball & 155 & 62.0 \\
Sports Age & $\mathrm{f}$ & $\%$ \\
$1-5$ & 84 & 33.6 \\
$6-10$ & 104 & 41.6 \\
11 or More & 62 & 24.8 \\
Weekly Training & $\mathrm{f}$ & $\%$ \\
$1-2$ & 213 & 85.2 \\
$3-4$ & 37 & 14.8 \\
Total & 250 & 100.0 \\
\hline
\end{tabular}


Table 2. Unpaired t-test results of differentiation status according to gender of personality traits and optimal performance levels of unilig athletes

\begin{tabular}{|c|c|c|c|c|c|c|c|}
\hline Variables & Gender & $\mathrm{n}$ & $\bar{x}$ & ss & $\mathbf{t}$ & sd & $p$ \\
\hline \multirow[b]{2}{*}{ Extroversion } & Female & 75 & 3.45 & 0.52 & \multirow{2}{*}{1.14} & \multirow[b]{2}{*}{248} & \multirow[b]{2}{*}{0.257} \\
\hline & Male & 175 & 3.37 & 0.52 & & & \\
\hline \multirow{2}{*}{ Conscientiousness } & Female & 75 & 3.47 & 0.54 & \multirow{2}{*}{-0.14} & \multirow{2}{*}{248} & \multirow{2}{*}{0.891} \\
\hline & Male & 175 & 3.48 & 0.47 & & & \\
\hline \multirow{2}{*}{ Openness } & Female & 75 & 3.60 & 0.57 & \multirow{2}{*}{0.67} & \multirow{2}{*}{248} & \multirow{2}{*}{0.504} \\
\hline & Male & 175 & 3.55 & 0.50 & & & \\
\hline \multirow{2}{*}{ Agreeableness } & Female & 75 & 3.49 & 0.49 & \multirow{2}{*}{1.41} & \multirow{2}{*}{248} & \multirow{2}{*}{0.160} \\
\hline & Male & 175 & 3.40 & 0.44 & & & \\
\hline \multirow{2}{*}{ Neuroticism } & Female & 75 & 3.32 & 0.57 & \multirow{2}{*}{0.33} & \multirow{2}{*}{248} & \multirow{2}{*}{0.745} \\
\hline & Male & 175 & 3.29 & 0.53 & & & \\
\hline \multirow{2}{*}{ Personality General } & Female & 75 & 3.47 & 0.40 & \multirow{2}{*}{0.93} & \multirow{2}{*}{248} & \multirow{2}{*}{0.355} \\
\hline & Male & 175 & 3.42 & 0.35 & & & \\
\hline \multirow{2}{*}{ Task Difficulty - Skill Balance } & Female & 75 & 3.45 & 0.67 & \multirow[t]{2}{*}{0.273} & \multirow[t]{2}{*}{248} & \multirow[t]{2}{*}{0.785} \\
\hline & Male & 175 & 3.42 & 0.72 & & & \\
\hline \multirow{2}{*}{$\begin{array}{l}\text { Action-Consciousness } \\
\text { Combination }\end{array}$} & Female & 75 & 3.56 & 0.83 & 1.218 & 248 & 0.224 \\
\hline & Male & 175 & 3.43 & 0.78 & & & \\
\hline Onon Goalc & Female & 75 & 3.93 & 0.78 & 2.015 & 248 & $0.045^{*}$ \\
\hline Upen Godis s the & Male & 175 & 3.71 & 0.81 & & & \\
\hline Cnosific Eondhask & Female & 75 & 3.86 & 0.81 & 2.06 & 248 & $0.040^{*}$ \\
\hline specmic reeunder & Male & 175 & 3.63 & 0.81 & & & \\
\hline Consontration on Tast & Female & 75 & 3.71 & 0.91 & -0.286 & 248 & 0.775 \\
\hline Concentration on IdSK & Male & 175 & 3.74 & 0.71 & & & \\
\hline Conse of Control & Female & 75 & 3.85 & 0.72 & 2.292 & 248 & $0.023^{*}$ \\
\hline 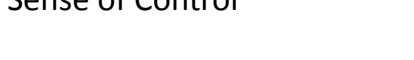 & Male & 175 & 3.60 & 0.84 & & & \\
\hline 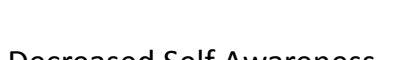 & Female & 75 & 3.67 & 0.92 & 1.571 & 248 & 0.117 \\
\hline Decreased sen Awareness & Male & 175 & 3.47 & 0.90 & & & \\
\hline$C_{0}$ & Female & 75 & 3.81 & 0.79 & 1.989 & 248 & $0.048^{*}$ \\
\hline e & Male & 175 & 3.60 & 0.78 & & & \\
\hline Achioving Col Evnorionco & Female & 75 & 3.87 & 0.86 & 0.167 & 248 & 0.867 \\
\hline Acrieving Godi Lxperiente & Male & 175 & 3.85 & 0.90 & & & \\
\hline Optimal Performance Mood & Female & 75 & 3.75 & 0.61 & 1.688 & 248 & 0.093 \\
\hline General & Male & 175 & 3.60 & 0.60 & & & \\
\hline
\end{tabular}


Table 3. Unpaired t-test results of differentiation status according to branch of personality traits and optimal performance levels of unilig athletes

\begin{tabular}{|c|c|c|c|c|c|c|c|}
\hline Variables & $\begin{array}{l}\text { Sports } \\
\text { Branch }\end{array}$ & $\mathbf{n}$ & $\bar{x}$ & ss & $\mathbf{t}$ & sd & $\mathbf{p}$ \\
\hline \multirow{2}{*}{ Extroversion } & Basketball & 95 & 3.66 & 0.43 & \multirow{2}{*}{7.039} & \multirow{2}{*}{248} & \multirow{2}{*}{$0.000 *$} \\
\hline & Volleyball & 155 & 3.22 & 0.50 & & & \\
\hline \multirow{2}{*}{ Conscientiousness } & Basketball & 95 & 3.68 & 0.43 & \multirow[t]{2}{*}{5.517} & \multirow[t]{2}{*}{248} & \multirow[t]{2}{*}{$0.000^{*}$} \\
\hline & Volleyball & 155 & 3.35 & 0.48 & & & \\
\hline \multirow{2}{*}{ Openness } & Basketball & 95 & 3.79 & 0.40 & \multirow[t]{2}{*}{5.773} & \multirow[t]{2}{*}{248} & \multirow[t]{2}{*}{$0.000 *$} \\
\hline & Volleyball & 155 & 3.42 & 0.54 & & & \\
\hline \multirow{2}{*}{ Agreeableness } & Basketball & 95 & 3.57 & 0.39 & \multirow[t]{2}{*}{3.943} & \multirow[t]{2}{*}{248} & \multirow[t]{2}{*}{$0.000 *$} \\
\hline & Volleyball & 155 & 3.34 & 0.47 & & & \\
\hline \multirow{2}{*}{ Neuroticism } & Basketball & 95 & 3.55 & 0.49 & \multirow[t]{2}{*}{6.023} & \multirow[t]{2}{*}{248} & \multirow[t]{2}{*}{$0.000^{*}$} \\
\hline & Volleyball & 155 & 3.15 & 0.52 & & & \\
\hline \multirow{2}{*}{ Personality General } & Basketball & 95 & 3.66 & 0.29 & \multirow{2}{*}{8.373} & \multirow{2}{*}{248} & \multirow{2}{*}{$0.000 *$} \\
\hline & Volleyball & 155 & 3.30 & 0.34 & & & \\
\hline \multirow{2}{*}{ Task Difficulty - Skill Balance } & Basketball & 95 & 3.61 & 0.62 & \multirow[t]{2}{*}{3.308} & \multirow[t]{2}{*}{248} & \multirow[t]{2}{*}{$0.001^{*}$} \\
\hline & Volleyball & 155 & 3.31 & 0.73 & & & \\
\hline \multirow{2}{*}{ Action-Consciousness Combination } & Basketball & 95 & 3.81 & 0.62 & 5.527 & 248 & $0.000 *$ \\
\hline & Volleyball & 155 & 3.26 & 0.82 & & & \\
\hline Onen Goals & Basketball & 95 & 4.14 & 0.59 & 5.968 & 248 & $0.000^{*}$ \\
\hline Geril udis & Volleyball & 155 & 3.55 & 0.84 & & & \\
\hline Cnocific Eondhork & Basketball & 95 & 3.99 & 0.67 & 4.578 & 248 & $0.000 *$ \\
\hline specilc reeadack & Volleyball & 155 & 3.52 & 0.85 & & & \\
\hline Concentration on Task & Basketball & 95 & 4.06 & 0.62 & 5.718 & 248 & $0.000^{*}$ \\
\hline 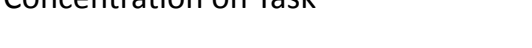 & Volleyball & 155 & 3.52 & 0.78 & & & \\
\hline & Basketball & 95 & 4.01 & 0.58 & 5.394 & 248 & $0.000 *$ \\
\hline sense of control & Volleyball & 155 & 3.47 & 0.87 & & & \\
\hline Decreased Self Awareness & Basketball & 95 & 3.87 & 0.81 & 4.902 & 248 & $0.000^{*}$ \\
\hline 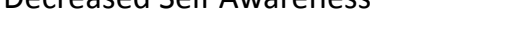 & Volleyball & 155 & 3.32 & 0.90 & & & \\
\hline Conversion of Time & Basketball & 95 & 3.97 & 0.60 & 5.195 & 248 & $0.000^{*}$ \\
\hline Conversion or IIme & Volleyball & 155 & 3.47 & 0.83 & & & \\
\hline Achieving Gol Fxnerience & Basketball & 95 & 4.22 & 0.63 & 5.239 & 248 & $0.000 *$ \\
\hline 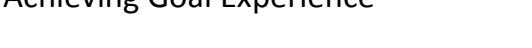 & Volleyball & 155 & 3.64 & 0.95 & & & \\
\hline & Basketball & 95 & 3.97 & 0.45 & & 248 & $0.000 *$ \\
\hline Uptımal Perrormance IVIood General & Volleyball & 155 & 3.45 & 0.61 & 1.084 & 248 & 0.000 \\
\hline
\end{tabular}

According to unpaired t-test results to find out whether the difference between personality traits of Unilig atlethes and their optimal performance mood levels is statistically significant or not in terms of gender subscale there is no a meaningful difference $(\mathrm{p}>0.05)$. In contrast, open goals, specific feedback, sense of control, conversation of time subscales cause statistically meaningful differences $(\mathrm{p}<0.05)$.

According to the results of unpaired t-test conducted to test whether the difference of perceptions of personality scale and optimal performance mood subscales of the unilig athletes participated in the study is statistically significant according to sports branch, there was significant difference between participants' personality scale and optimal performance mood scale general and subscale scores and sports branch $(\mathrm{p}<0.01)$.

According to the results of unpaired t-test conducted to test whether the difference of perceptions of personality scale and optimal performance mood subscales of the unilig athletes participated in the study is statistically significant according to sports branch, there was no significant difference only in agreeableness subscale scores of the participants $\left({ }^{*}=\mathrm{p}>0.01,{ }^{* *}=\mathrm{p}>0.05\right)$.

According to the results of the scale scores conducted to determine the Personality Scale and Optimal Performance Moods of Unilig Athletes, it is determined that there was a high positive relationship between personality traits and optimal performance $\operatorname{mood}(\mathrm{p}<0.01, \mathrm{p}=0.000, \mathrm{r}=0.608)$. 
Table 4. Unpaired t-test results of differentiation status according to weekly training hours of personality traits and optimal performance levels of unilig athletes

\begin{tabular}{|c|c|c|c|c|c|c|c|}
\hline Variables & $\begin{array}{l}\text { Weekly Training } \\
\text { Hours }\end{array}$ & $\mathbf{n}$ & $\bar{x}$ & ss & $\mathbf{t}$ & sd & $\mathbf{p}$ \\
\hline \multirow{2}{*}{ Extroversion } & $1-2$ & 213 & 3.44 & 0.50 & \multirow{2}{*}{3.646} & \multirow{2}{*}{248} & \multirow{2}{*}{$0.000^{*}$} \\
\hline & $3-4$ & 37 & 3.11 & 0.55 & & & \\
\hline \multirow{2}{*}{ Conscientiousness } & $1-2$ & 213 & 3.54 & 0.46 & \multirow[t]{2}{*}{5.526} & \multirow[t]{2}{*}{248} & \multirow[t]{2}{*}{$0.000 *$} \\
\hline & $3-4$ & 37 & 3.09 & 0.48 & & & \\
\hline \multirow{2}{*}{ Openness } & $1-2$ & 213 & 3.61 & 0.51 & \multirow[t]{2}{*}{3.826} & \multirow[t]{2}{*}{248} & \multirow[t]{2}{*}{$0.000^{*}$} \\
\hline & $3-4$ & 37 & 3.26 & 0.55 & & & \\
\hline \multirow{2}{*}{ Agreeableness } & $1-2$ & 213 & 3.44 & 0.46 & \multirow[t]{2}{*}{1.433} & \multirow[t]{2}{*}{248} & \multirow[t]{2}{*}{0.153} \\
\hline & $3-4$ & 37 & 3.33 & 0.47 & & & \\
\hline \multirow{2}{*}{ Neuroticism } & $1-2$ & 213 & 3.34 & 0.55 & \multirow[t]{2}{*}{2.762} & \multirow[t]{2}{*}{248} & \multirow[t]{2}{*}{$0.006^{*}$} \\
\hline & $3-4$ & 37 & 3.07 & 0.45 & & & \\
\hline \multirow{2}{*}{ Personality General } & $1-2$ & 213 & 3.48 & 0.35 & \multirow{2}{*}{4.904} & \multirow{2}{*}{248} & \multirow{2}{*}{$0.000 *$} \\
\hline & $3-4$ & 37 & 3.18 & 0.31 & & & \\
\hline \multirow{2}{*}{ Task Difficulty - Skill Balance } & $1-2$ & 213 & 3.47 & 0.71 & \multirow[t]{2}{*}{2.180} & \multirow[t]{2}{*}{248} & \multirow[t]{2}{*}{$0.030 * *$} \\
\hline & $3-4$ & 37 & 3.20 & 0.67 & & & \\
\hline \multirow{2}{*}{$\begin{array}{l}\text { Action-Consciousness } \\
\text { Combination }\end{array}$} & $1-2$ & 213 & 3.52 & 0.80 & & & O $7 *$ \\
\hline & $3-4$ & 37 & 3.18 & 0.68 & 2.409 & 248 & $0.017^{* *}$ \\
\hline Onen Goals & $1-2$ & 213 & 3.86 & 0.77 & 3.969 & 248 & $0.000 *$ \\
\hline Open Goals & $3-4$ & 37 & 3.30 & 0.89 & & & \\
\hline Snerifir Feodhack & $1-2$ & 213 & 3.78 & 0.79 & & & \\
\hline Specific Feedback & $3-4$ & 37 & 3.22 & 0.81 & 3.931 & 248 & $0.000^{*}$ \\
\hline & $1-2$ & 213 & 3.80 & 0.76 & 3.532 & 248 & $0.000 *$ \\
\hline Concentration on Iask & $3-4$ & 37 & 3.32 & 0.71 & & & \\
\hline & $1-2$ & 213 & 3.76 & 0.79 & 4.183 & 248 & $0.000 *$ \\
\hline Sense of Control & $3-4$ & 37 & 3.18 & 0.79 & & & \\
\hline Decreased Self Awareness & $1-2$ & 213 & 3.61 & 0.90 & 3623 & 248 & คดกด* \\
\hline & $3-4$ & 37 & 3.04 & 0.83 & 3.023 & 240 & 0.000 \\
\hline Conversion of Time & $1-2$ & 213 & 3.72 & 0.80 & 3.095 & 248 & $0.002 *$ \\
\hline Conversion of I Ime & $3-4$ & 37 & 3.30 & 0.59 & & & \\
\hline Achieving Goal Exnerience & $1-2$ & 213 & 3.98 & 0.83 & 5.413 & 248 & $0.000 *$ \\
\hline Acrileving Godi experience & $3-4$ & 37 & 3.17 & 0.89 & & & \\
\hline Optimal Performance Mood & $1-2$ & 213 & 3.72 & 0.60 & 1021 & 218 & ค ค ค * \\
\hline General & $3-4$ & 37 & 3.21 & 0.49 & 4.924 & 248 & $0.000^{\circ}$ \\
\hline
\end{tabular}

Table 5. Results of pearson correlation analysis to determine the relationship between personality traits and optimal performance mood of unilig athletes

\begin{tabular}{ll}
\hline Variables & Optimal Performance Mood Scale General \\
\hline \multirow{2}{*}{ Personality General Scale } & $.608^{* *}$ \\
& .000 \\
\hline
\end{tabular}

\section{Discussion}

The analysis to test the gender variable shows there is no significant difference between personality traits of male and female Unilig tlethes. The subscale perceptions of optimal performance mood state causes meaningful difference in terms of gender difference.

When the data obtained in our study was evaluated, there was no significant difference according to gender variable of perceptions of personality scale and optimal performance mood subscales. Nas [16] stated that there was no difference between the students studying in the sports departments of universities according to the gender variable. The data obtained are also similar to the study conducted by Gözmen and Aşçı [17] on optimal performance, mood, personality and perfectionism in athletes. 
Yildız et al., [18] concluded that gender variable causes a meaningful difference in optimal performance mood states of 207 atlethes. While Tok [19] asserted gender difference causes no meaningful difference in extreme sports atlethes Lonchbaum ve ark. [20] remarked that indivduals who take regular exercieses and ones who don't take regular exercieses have similar personality traits.

Contrary to the findings, Eryücel [21] found out that gender causes no significant difference in optimal performance mood states of individual atlethes and team players when their optimal performance mood states and soliloquy.Acording to the data of the study sports branch variable causes meaningful differences in personality traits and optimal performance moods of Unilig atlethes.

Bernier et al., [22] examined the awareness and acceptance of performance on athletes in their study. They compared elite swimmers with young elite golfers. Optimum performance levels of both groups were found to be similar. In another part of the research, 7 elite young golfers were included in the psychological skills training program and it was concluded that the program based on awareness and acceptance contributed to the increase in performance in competition. There is a significant difference between volleyball players and basketball players according to the sport branches of perceptions of personality scale and optimal performance mood subscales of UNILIG athletes. It can be said that obtaining different results according to different branch variables in both studies is due to the fact that Barnier et al. [22] conducted the study on individual athletes. On the other hand, Yanar v. d. [23] states that weekly training duration or sports cause no significant difference in optimal performance mood states.

Robazza and Bortoli [24] examined the mood, normative anger and anxiety levels of 197 rugby athletes in their study. Consequently, it is seen that rugby players have moderate anger frequency of symptoms. Similarly, it was concluded that the players had moderate anxiety and their anxiety symptoms decreased if they felt selfconfidence. In our study, it is seen that there is a high positive relationship between personality traits and optimal performance moods. These results are similar to the results of the study conducted by Robazza and Bartoli [24].

Altıntaş et al. [25] concluded in their study on 167 elite male athletes that the motivation levels of the athletes had an effect on the optimal performance mood according to the branch variable. In other words, while interior motivation facilitates the formation of optimal performance mood in athletes, exterior motivation seems to prevent this situation. In our study, a significant difference was found between the general and subscales of personality scale and optimal performance mood scale and sports branches. This results in support of our study.

According to our study results, there is a higly positive relationship between personality traits and optimal performance mood states of the participants. It can be concluded that individuals with high personality trait scores are more likely to experience optimal performance mood.

Likewise our study results, there are other researches which state similar findings about a positive correlation between personal traits and optimal performance mood states. Gozmen and Aşçı put forth that there is a positive correlation between personal traits and optimal performance moods of elite atlethes. Also Ross and Kaiser [26] and Ullen et al. [11] asserted that, similar to our findings, there is a positive correlation between personal traits and optimal performance moods of atlethes. There are further researches with similar results [27,28,29].

Moreno says that is it quite expected that there is a positive relationship between personal traits and optimal performance moods. According to Moreno [30] atlethes with self control and open for improvement traits have inner motivation for the activities and this let them to experience optimal performance mood.

\section{Conclusion}

According to the results of the examination of the Personality Traits and Optimal Performance Moods of the total of $(n=250)$ male-female Unilig athletes, it is concluded that the validity and reliability aspects of the measurement tools are valid in our study as in previous studies.

In our study, when examined the difference of Unilig atlethes' personality scale and optimal performance mood subscale perceptions in terms of gender variable, it is concluded that there is a meaningful difference in optimal performance mood subscale.

In our study, when examined the differences in perceptions of personality scale and optimal performance mood subscales of Unilig athletes according to gender; it is concluded that there is no significant difference according to the gender of the participants.

According to the sports branches of perceptions of personality scale and optimal performance mood subscales of Unilig athletes; it is concluded that there is a significant difference between athletes' general and subscales scores of personality scale and optimal performance mood scale and sports branches.

According to weekly training hours of perceptions of personality scale and optimal performance mood subscales of Unilig athletes, there is a significant difference in agreeableness subscale.

According to score results of scale carried out to determine the personality scale and optimal performance mood of Unilig athletes, it is concluded that personality traits and optimal performance moods affect one another positively.

\section{Conflict of interests}

The authors declare that there is no conflict of interests. 


\section{References}

1. Hefferon K, Boniwell L. Positive Psychology. Theory, Research and Applications. Çeviren: Doğan T. Nobel Yayın: İstanbul; 2014.

2. Jackson SA, Thomas PR, Marsh HW, Smethurst CJ. Relationships between flow, self-concept, psycho- logical skills, and performance. Journal of Applied Sport Psychology, 2001; 13, 129- 153. https://doi.org/10.1080/104132001753149865

3. Csikszentmihalyi M. Beyond Boredom and Anxiety. JosseyBass: San Francisco; 1995.

4. Csikszentmihalyi M. Finding flow: The psychology of engagement with everyday life. Basic Books; 1997.

5. Moneta GB. The flow experience across cultures. Journal of Happiness Studies, 2004; 5(2): 115- 121. https://doi.org/10.1023/B:JOHS.0000035913.65762.b5

6. Asakawa K. Japanese College Students : How do they. Journal of Happiness Studies, 2004; 5:123-54. https://doi.org/10.1023/B:JOHS.0000035915.97836.89

7. Aşçı FH, Çağlar E, Eklund RC, Altıntaş A, Jackson S. Durumluk ve Sürekli Optimal Performans Duygu Durum-2 Ölçekleri'nin Uyarlama Çalışması [State and Continuous Optimal Performance Emotion Status-2 Scales Adaptation Study]. Hacettepe Journal of Sport Sciences, 2007; 18(4): 182-196. (In Turkish)

8. Jackson SA, Marsh HW. Development and validation of a scale to measure optimal experience: The flow state scale. Journal of Sport \& Exercise Psychology, 1996; 18: 17- 35. https://doi.org/10.1123/jsep.18.1.17

9. Smith E, Hoeksema S, Fredrickson B, Loftus G. Atkinson and Hilgrad's Introduction to Psychology. Psikolojiye Giriş. 14th ed. Çeviren: Öncül Ö, Ferhatoğlu D, Arkadaş Yayınevi; Ankara; 2012. P. 450-480.

10.Pervin LA, John OP. Personality: Theory and research (12th ed.). Oxford: John Wiley and Sons; 2013

11.Ullen F, Manzano O, Almeida R, Magnusson PKE, Pedersen NL, Nakamura J, Csikszentmihalyi M, Madison G. Proneness for psychological flow in everyday life: Associations with personality and intelligence. Personality and Individual Differences, 2012; 52 (2): 167- 172. https://doi.org/10.1016/j.paid.2011.10.003

12.Karasar N. Bilimsel Araștırma Yöntemi [Scientific Research Method]. Ankara: Nobel Yayın Dağıtım; 2010

13.Jackson SA, Eklund RC. The Flow Scales Manual. Morgantown, WV: Fitness Information Technology; 2004.

14.Benet-Martínez V, John OP. Los Cinco Grandes across cultures and ethnic groups: multitrait multimethod analyses of the Big Five in Spanish and English. Journal of Personality and Social Psychology, 1998; 75(3): 729- 750. https://doi.org/10.1037/0022-3514.75.3.729

15.Schmitt DP, Allik J, McCrae RR, Benet-Martinez V. The GeographicDistribution ofBigFivePersonalityTraits:Patterns and Profiles of Human Self-Description Across 56 Nations. Journal of Cross-Cultural Psychology, 2007;38;(2): 173-212. https://doi.org/10.1177/0022022106297299

16.Nas K. The effect of the physical education and sports high school students'personal characteristics to gender, age and sports type. The Journal, 2018; 11(57):100-109.

17.Gözmen A, Aşç1 F. Sporcularda optimal performans duygu durumunun yordanmasında beş faktörlü kişilik özelliklerinin ve mükemmeliyetçiliğin rolü [The role of five-factor personality traits and perfectionism in predicting optimal performance mood in athletes]. Spor Bilimleri Dergisi, 2016; 27 (1): 40-48. (In Turkish) https://doi.org/10.17644/sbd.251312

18.Yıldız AB, Gülşen DBA, Yılmaz B. Sporcuların optimal performans duygu durumunun yaşam tatminleri üzerindeki etkisi. Niğde University Journal of Physical Education And Sport Sciences. 2015; 9: 90-97.

19.Tok S. The big five personality traits and risky sport participation. Social Behavior and Personality: An International Journal, 2011; 39(8): 1105- 1111. https://doi.org/10.2224/sbp.2011.39.8.1105

20.Lonchbaum MR, Rhodes RE, Stevenson SJ, Surles J, Stevens T, Wang CKJ. Does gender moderate the exercising personality? An examination of continuous and stage-based exercise. Psychology, Health and Medicine, 2010; 15(1): 50- 60. https://doi.org/10.1080/13548500903443449

21.Eryucel ME. An Analysis of Self-Talk and Flow State of Athletes in Team and Individual Sports. Journal of Education and Learning, 2019;8:286. https://doi.org/10.5539/jel.v8n2p286

22.Bernier M, Thienot E, Codron R, Fournier JF. Mindfulness and acceptance approaches in sport performance. Journal of Clinical Sport Psychology, 2009; 3(4): 320-333. https://doi.org/10.1123/jcsp.3.4.320

23. Yanar S, Kirandi O, Ates O, Ehlizoglu M, Celikbilek S. Investigation of the correlation between athletes' training continuity and flow experience. International Journal of Academic Research, 2017;9:37-40. https://doi.org/10.7813/2075-4124.2017/9-1/B.6

24.Robazza C, Bortoli L. Perceived impact of anger and anxiety on sporting performance in rugby players. Psychology of Sport and Exercise, 2007; 8(6): 875-896. https://doi.org/10.1016/j.psychsport.2006.07.005

25.Altıntaş A, Kelecek S, Aşçı F. Elit sporcularda durumsal güdülenme ve optimal performans duygu durumu arasındaki ilişki [Relationship between situational motivation and optimal performance mood in elite athletes]. Pamukkale Spor Bilimleri Dergisi, 2013; 4(4): 14-21. (In Turkish)

26. Ross SR, Keiser HN. Autotelic personality through a fivefactor lens: Individual differences in flow-propensity. Personality and Individual Differences, 2014; 59, 3-8. https://doi.org/10.1016/j.paid.2013.09.029

27.Noftle EE, Robins RW. Personality predictors of academic outcomes: big five correlates of GPA and SAT scores. Journal of Personality and Social Psychology, 2007; 93(1): 116-130. https://doi.org/10.1037/0022-3514.93.1.116

28.Roberts BW, Walton KE, Bogg T. Conscientiousness and Health Across the Life Course. Review of General Psychology, 2005; 9(2): 156-168. https://doi.org/10.1037/1089-2680.9.2.156

29.Hills P, Argyle M. Happiness, introversionextraversion and happy introverts. Personality and Individual Differences, 2001; 30(4): 595-608. https://doi.org/10.1016/S0191-8869(00)00058-1

30.Moreno MJA, Cervelló GE, González-Cutre CD. Relationships among goal orientations, motivational climate and flow in adolescent athletes: differences by gender. The Spanish Journal of Psychology, 2008; 11(1): 181- 191. https://doi.org/10.1017/S1138741600004224 


\section{Information about the authors:}

Çeviker A. (Corresponding author); http://orcid.org/0000-0002-6566-1251; abdulkerimceviker@hitit.edu.tr; Hitit University, Sports Science Faculty; Çevre Yolu Bulvarı 19030, Çorum, Turkey.

Özlü K.; http://orcid.org/0000-0003-1839-5437; kurtulusozlu@hitit.edu.tr; Hitit University, Sports Science Faculty; Çevre Yolu Bulvarı 19030, Çorum, Turkey.

Deryahanoğlu G.; http://orcid.org/0000-0001-5186-3453; gamzederyahanoglu@hitit.edu.tr; Hitit University, Sports Science Faculty; Çevre Yolu Bulvarı 19030, Çorum, Turkey.

Demirdöken Ç.; http://orcid.org/0000-0003-0212-2872; cisemunlu@hitit.edu.tr; Hitit University, Sports Science Faculty; Çevre Yolu Bulvarı 19030, Çorum, Turkey.

Turkay H.; http://orcid.org/0000-0002-7851-2757; hikmetturkay06@gmail.com; High School of Physical Education And Sports, Kafkas University; 36500 Sarıkamış, Kars, Turkey.

Cite this article as:

Ceviker A, Ozlu K, Deryahanoglu G, Demirdoken C, Turkay H. The examination of the personality traits and optimal performance mood of the university athletes. Pedagogy of physical culture and sports, 2020;24(1):4-11.

https://doi.org/10.15561/18189172.2020.0101

This is an Open Access article distributed under the terms of the Creative Commons Attribution License, which permits unrestricted use, distribution, and reproduction in any medium, provided the original work is properly cited (http://creativecommons.org/licenses/by/4.0/deed.en).

Received: 15.09 .2019

Accepted: 16.10.2019; Published: 10.11.2019 